CASE REPORT

\title{
Erdheim-Chester disease: case report with multisystemic manifestations including testes, thyroid, and lymph nodes, and a review of literature
}

\author{
S-Y Sheu, R R Wenzel, C Kersting, R Merten, F Otterbach, K W Schmid
}

J Clin Pathol 2004;57:1225-1228. doi: 10.1136/icp.2004.018481

Erdheim-Chester disease is a rare non-Langerhans' cell histiocytosis with characteristic radiological and histological features. This entity is defined by a mononuclear infiltrate consisting of lipid laden, foamy histiocytes that stain positively for CD68. About half of those affected have extraskeletal manifestations, including involvement of the hypothalamus-pituitary axis, lung, heart, retroperitoneum, skin, liver, kidneys, spleen, and orbit. This report describes the case of a 50 year old white man who presented with hypogonadism and diabetes insipidus. At necropsy, extensive organ involvement was found, including the testes, thyroid, and lymph nodes. This is the first report of thyroid and lymph node infiltration in this disease. Because of the endocrinological symptoms, neurosarcoidosis and hypophysitis are important diseases in the differential diagnosis. This report also includes a review of the literature concerning rare organ manifestations and patients presenting primarily with similar symptoms.

$\mathrm{T}$ here are several definitions of Erdheim-Chester disease relating to either the radiological or histopathological hallmarks. In fact Erdheim-Chester is a rare nonLangerhans' cell histiocytosis of unknown aetiology. It affects middle aged individuals and there is no sex predilection. First described in 1930 by William Chester as a novel lipogranulomatous disorder, it was later termed Erdheim-Chester disease after the pathologist Erdheim, with whom he worked. ${ }^{1}$ "Respiratory distress, extensive pulmonary fibrosis, and
cardiac failure are the most common causes of death"

This entity is defined by a mononuclear infiltrate consisting of lipid laden, foamy histiocytes, which are found mainly in the long bones of the lower extremities, the central nervous system, retroperitoneum, lung, heart, liver, spleen, skin, and orbit. The diagnosis is based on almost pathognomonic radiographic signs characterised by bilateral, symmetrical osteosclerosis involving metaphyseal and diaphyseal regions, with sparing of the epiphyses, combined with histological features. About half of the patients have extraskeletal manifestations such as fever, weight loss, weakness, exophthalmos, diabetes insipidus, dysuria, abdominal pain, and obstructive renal impairment as a result of retroperitoneal involvement. Neurological manifestations include ataxia, paresis, and diabetes insipidus. The prognosis depends on the extent and distribution of the extraskleletal manifestations. Respiratory distress, extensive pulmonary fibrosis, and cardiac failure are the most common causes of death. Corticosteroids, chemotherapy, surgical resection, and radiotherapy have been used to combat Erdheim-Chester disease and there is no consensus concerning the best treatment. The differential diagnosis includes Langerhans' cell histiocytosis, metabolic disorders, and malignancies.

The patient that we report showed extensive manifestations in almost every organ examined at necropsy, including rare localisations such as the testes, thyroid, and lymph nodes.

The thyroid revealed a moderate infiltration of foamy, lipid laden histiocytes in the interlobular septa between the follicles (fig lB). The mediastinal lymph nodes showed a diffuse infiltration of macrophages with a pale and fine granular cytoplasm in the sinus (fig lC).

\section{CASE REPORT}

A 48 year old man was admitted with diabetes insipidus and hypogonadism. Cerebral magnetic resonance imaging showed a $0.5 \mathrm{~cm}$ thickened pituitary stalk. Microscopally, the tumour mass consisted of non-specific inflammatory cells and the diagnosis "pseudoinflammatory" tumour was made. Hypophyseal stimulating tests revealed a gonadotrophic insufficiency, followed by a corticotrophin and thyrotrophin releasing hormone deficit. Two years later he presented with progressive dyspnoea with pleural effusions. His serum creatinine was raised at $26 \mathrm{mg} /$ litre. This was the result of fibrosis of the retroperitoneal space encasing both ureters. The obstructive renal impairment led to nephrectomy of both kidneys.

Serum cholesterol was within the normal range (1700 mg/ litre), but serum triglycerides were raised $(5060 \mathrm{mg} / \mathrm{litre})$. The patient had no history of bone pain.

The patient's terminal course was complicated by atrial and ventricular arrhythmias and legionella and mycobacterium tuberculosis pneumonia. He died as a result of respiratory and cardiac failure.

All tissue specimens obtained from the pituitary gland, both kidneys, retroperitoneum, and the pleural fluid during the patient's lifetime revealed inflammatory cells only.

\section{PATHOLOGICAL FINDINGS}

At necropsy we found several soft and fat-like yellow masses measuring up to $4.5 \times 4 \times 2 \mathrm{~cm}$ in the myocardium/pericardium of the right atrium. The retroperitoneum revealed extensive fibrosis, which led to a successive bilateral nephrectomy before death. Histologically, the tissue specimens from the lungs, heart, brain, kidneys, lymph nodes, testes, and thyroid showed infiltrates of histiocytes with a pale staining, foamy, and finely granular cytoplasm. Both kidneys showed a xanthogranulomatous pyelonephritis with fibrous perinephritis. The lung specimens reveal a greatly thickened and fibrous pleura, with fibrosis of the interlobular septa and the perivascular interstitium. The testicular tubules 

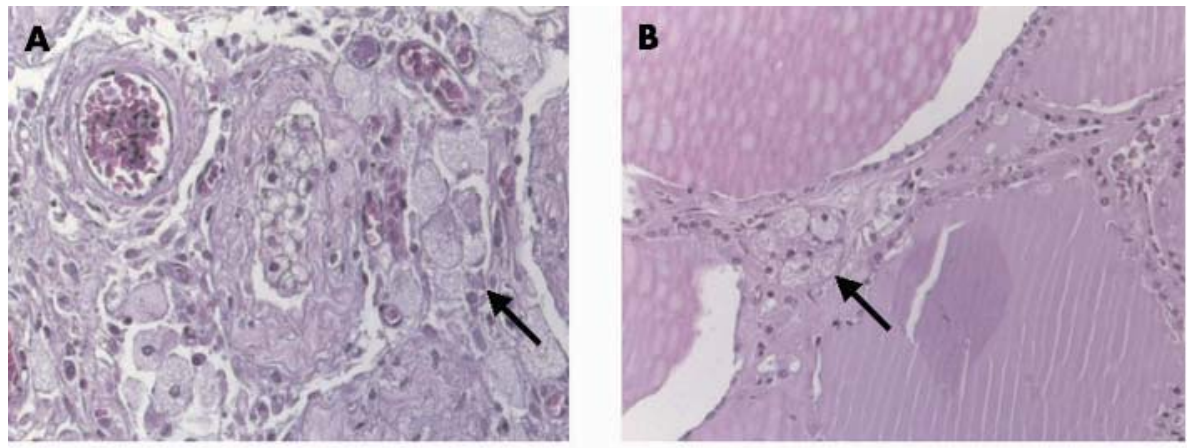

Figure 1 Infiltration of lipid laden macrophages (arrows) in (A) testis, (B) thyroid, and (C) lymph node. (D) Testis, immunohistochemistry using antibodies against CD68.
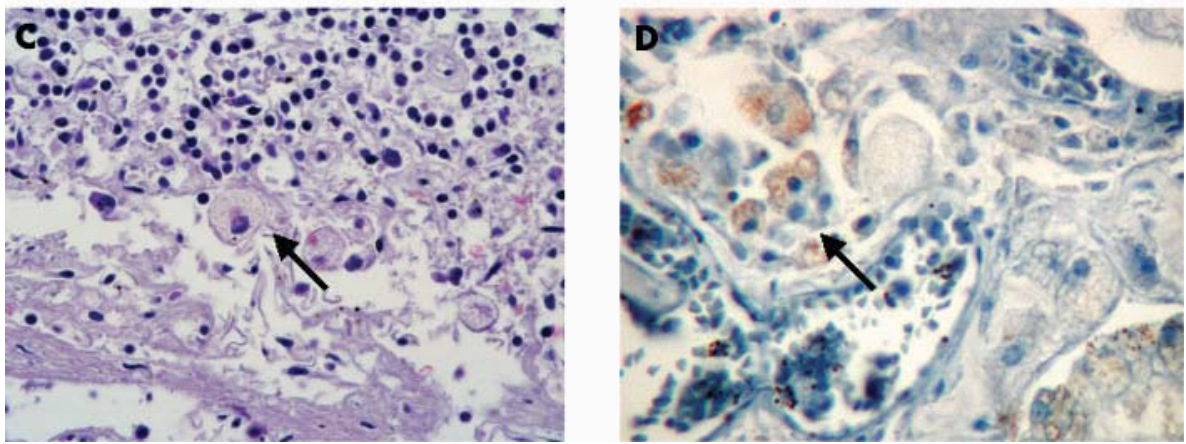

were totally atrophied and replaced by hyaline and collagenous ghosts as a result of hypogonadism. Sections of both testes revealed an intratubular and interstitial infiltrate of macrophages with the same appearance. The nuclei were round and lacked the irregular configurations typical of Langerhans' cells. Interstitial Leydig cells were not present (fig lA).

Immunohistochemical stains for CD68 of sections of the lung, myocardium/pericardium, kidneys, thyroid, testes (fig 1D), and lymph nodes were positive, whereas no reaction was detectable with CDla and S-100.

The patient also showed bilateral eyelid xanthelasmas.

\section{DISCUSSION}

Erdheim-Chester disease is a rare, non-Langerhans' cell histiocytosis of unknown aetiology. There are typical radiographical and pathological features, which can lead to the diagnosis, but the clinical spectrum shows a broad variation, ranging from asymptomatic tissue infiltration to fulminant multisystem organ failure. The patient we report was admitted with polydipsia and hypogonadism. Cerebral magnetic resonance imaging showed a $0.5 \mathrm{~cm}$ thickened pituitary stalk. Microscopally, the tumour mass consisted of non-specific inflammatory cells and a diagnosis of "pseudoinflammatory" tumour was made. Although our patient lacked the most frequently occurring symptom of bone pain of the lower extremities, diabetes insipidus, dysfunction of the hypothalamic-pituitary axis in combination with an infiltration of mononuclear cells with foamy cytoplasm in almost every examined organ at necropsy is compatible with Erdheim-Chester disease. However, involvement of the testes, thyroid, and lymph nodes is uncommon. A review of the literature revealed three cases of testes involvement (table 1), ${ }^{2-4}$ one case of thyroid involvement, ${ }^{5}$ and (to our knowledge) no case with lymph node infiltration.

The only involvement of the thyroid was documented by Schmidt et al. They reported a 21 year old man with ErdheimChester disease and simultaneously decreased concentrations of low density lipoprotein cholesterol. ${ }^{5}$ We assume that immunohistochemistry was not performed. In addition, to our knowledge, this is the first time that involvement of the lymph nodes has been described. Two cases formerly reported

Table 1 Erdheim-Chester disease and testes involvement

\begin{tabular}{|c|c|c|c|c|c|}
\hline Ref & Age/sex & Clinical signs & Follow up & Biopsies & Histology \\
\hline 5 & $76 / M$ & $\begin{array}{l}\text { Diabetes insipidus, IDDM, } \\
\text { osteosclerosis, retroorbital mass }\end{array}$ & $\begin{array}{l}\text { Died } 10 \text { years later of } \\
\text { myocardial infarction }\end{array}$ & $\begin{array}{l}\text { Orbit, bones, kidney, } \\
\text { lung, right atrium, testes }\end{array}$ & $\begin{array}{l}\text { Hyalinisation and fibrosis, foamy lipid } \\
\text { laden macrophages, Touton cells, S-100 } \\
\text { negative }\end{array}$ \\
\hline 2 & $53 / M$ & $\begin{array}{l}\text { Leg cramp, flank pain, testicular } \\
\text { tenderness, obstructive uropathy, } \\
\text { renal insufficiency }\end{array}$ & Not reported & Testes & Not done \\
\hline 11 & $51 / M$ & $\begin{array}{l}\text { Hypophyseal mass, polydipsia, sexual } \\
\text { hormone and cortisol deficits, visual } \\
\text { disturbance, restrictive pulmonary } \\
\text { disease, interstitial pneumonia, } \\
\text { orchiectomy } 17 \text { years ago }\end{array}$ & Not reported & Pituitary gland, testes & $\begin{array}{l}\text { Xanthogranulomatous lesion: CD68 } \\
\text { positive, CD la negative, non-specific } \\
\text { granulomatous orchitis without further } \\
\text { specification }\end{array}$ \\
\hline Our case & $50 / M$ & Diabetes insipidus, hypogonadism & $\begin{array}{l}\text { Died } 2 \text { years after } \\
\text { diagnosis of } \\
\text { respiratory/cardiac } \\
\text { failure }\end{array}$ & $\begin{array}{l}\text { Kidney, brain, testes, } \\
\text { thyroid, lymph node }\end{array}$ & $\begin{array}{l}\text { Xanthogranulomatous nephritis, } \\
\text { retroperitoneal fibrosis, foamy histiocytes } \\
\text { positive for CD68 }\end{array}$ \\
\hline
\end{tabular}


Table 2 Differential diagnosis of Erdheim-Chester disease

\begin{tabular}{|c|c|c|c|}
\hline Diagnosis & Affected organs & Clinical symptoms & Pathology \\
\hline Erdheim-Chester disease & $\begin{array}{l}\text { Bones of lower extremities, CNS, } \\
\text { retroperitoneum, lung, heart, liver, } \\
\text { spleen, skin, orbit }\end{array}$ & $\begin{array}{l}\text { Bone pain, fever, weight loss, weakness, } \\
\text { exophthalmos, diabetes insipidus, } \\
\text { dysuria, abdominal pain, ataxia, paresis }\end{array}$ & $\begin{array}{l}\text { Mononuclear cells, foamy histiocytes } \\
\text { (CD68+, CD la-, S-100-), lymphocytes, } \\
\text { Touton giant cells, fibrosis }\end{array}$ \\
\hline Neurosarcoidosis & $\begin{array}{l}\text { Pituitary gland, mostly associated } \\
\text { with enlarged hilary lymph nodes }\end{array}$ & $\begin{array}{l}\text { Diabetes insipidus, adenopituitary failure, } \\
\text { amenorrhoea/galactorrhoea syndrome }\end{array}$ & $\begin{array}{l}\text { Epitheloid granulomas with Langhans' giant } \\
\text { cells and lymphocytes }\end{array}$ \\
\hline Langerhans' cell histiocytosis & $\begin{array}{l}\text { Skin, bones, lymph nodes, ear, } \\
\text { gum, lung, GIT, liver, CNS }\end{array}$ & $\begin{array}{l}\text { Petechial haemorrhages, erosive and } \\
\text { ulcerative lesions, lymphadenopathy, } \\
\text { bone pain, fractures, dyspnoea, } \\
\text { malabsorption, diabetes insipidus }\end{array}$ & $\begin{array}{l}\text { Proliferation of Langerhans cells (CD la+, S- } \\
100+\text { ), intracytoplasmic Birbeck granules } \\
\text { on electron microscopy }\end{array}$ \\
\hline Hypophysitis & $\begin{array}{l}\text { Adenohypophysis (rarely } \\
\text { neurohypophysis) }\end{array}$ & $\begin{array}{l}\text { Headache, diabetes insipidus, } \\
\text { amenorrhoea/galactorrhoea syndrome }\end{array}$ & $\begin{array}{l}\text { Common finding: lymphoplasmocytic } \\
\text { infiltration with focal or diffuse destruction }\end{array}$ \\
\hline \\
\hline \multicolumn{4}{|l|}{ Granulomatous } \\
\hline \multicolumn{4}{|l|}{ Xanthomatous } \\
\hline \multicolumn{4}{|l|}{ Xanthogranulomatous } \\
\hline Necrotising & & & \\
\hline
\end{tabular}

and cited by Bancroft and Berquist ${ }^{3}$ showed lymph node infiltration. The first one described a patient with hypothyroidism but no recognisable pathological evidence. ${ }^{6}$ The second case report dealt with Erdheim-Chester disease and congenital megacalices but there was no mention of lymph node involvement. ${ }^{7}$ The involvement of many organs including the testes, thyroid, and lymph nodes emphasises the multisystemic character of Erdheim-Chester disease.

Our patient was initially admitted with hypogonadism and diabetes insipidus. A biopsy taken from the pituitary gland revealed an inflammatory tumour. Inflammatory processes affecting the pituitary gland include infectious diseases, in addition to those with no known infectious agent, such as lymphocytic hypophysitis, sarcoidosis, and Langerhans' cell histiocytosis. ${ }^{8}$ Worldwide, only 12 cases with similar clinical features, but excluding a hypothalamic aetiology, Sheehan syndrome, or head injury, have been described so far. Five cases included neurosarcoidosis, ${ }^{9}$ four patients revealed hypophysitis, ${ }^{10-13}$ one patient had Langerhans' cell histiocytosis, ${ }^{14}$ and one presented with a suprasellar arachnoid cyst. ${ }^{15}$ In only one case was the diagnosis of Erdheim-Chester disease made. ${ }^{16}$ Based on the symptoms mentioned, the differential diagnosis of Erdheim-Chester disease includes all forms of hypophysitis, neurosarcoidosis, and Langerhans' cell histiocytosis involving the central nervous system (table 2). According to a clinicopathological study of 31 cases, hypophysitis can be histologically divided into five different types: lymphocytic, granulomatous, xanthogranulomatous, xanthomatous, and necrotising hypophysitis. ${ }^{13}$ The characteristic feature of xanthomatous hypophysitis, first described by Folkerth et al, ${ }^{17}$ is the presence of foamy to finely granular histiocytes that stain positively for CD68 and negatively for CDla and S-100. The hypophysitis of three patients reported by Folkerth et al and two cases by Tashiro and colleagues ${ }^{13}$ may be attributed to Erdheim-Chester disease because one of the patients presented with amenorrhoea, galactorrhoea, and diabetes insipidus. Neurosarcoidosis and Langerhans' cell histiocytosis must also be taken into consideration in the differential diagnosis and can be ruled out by histology and immunochemistry in combination with the clinical characteristics.

"The involvement of many organs including the testes, thyroid, and lymph nodes emphasises the multisystemic character of Erdheim-Chester disease"

Bone lesions are thought to be specific enough to suggest the diagnosis because they occur in all patients suffering

\section{Take home messages}

- We report a case of Erdheim-Chester disease, a rare non-Langerhans' cell histiocytosis with characteristic radiological and histological features (mononuclear infiltrate consisting of lipid laden, foamy histiocytes that stain positive for CD68)

- Our patient had extensive organ involvement at necropsy but the diagnosis of Erdheim-Chester disease was missed during his lifetime because the typical skeletal complaints were lacking

- To our knowledge, this is the first report of thyroid and lymph node infiltration in this disease

- Because of the endocrinological symptoms, neurosarcoidosis and hypophysitis are important diseases in the differential diagnosis

from Erdheim-Chester disease. However, when skeletal complaints are missing, as was the case in our patient, the diagnosis can be missed and not made until necropsy. Although there have been less than 100 published cases to date, the incidence of this disease is much higher, but the lack of diagnostic guidelines makes the diagnosis difficult. The combination of multisystemic symptoms, such as endocrinological abnormalities, respiratory and/or cardiac insufficiency, with typical radiological findings can direct the diagnosis. However, a histological and immunohistochemical examination is crucial for the diagnosis of Erdheim-Chester disease.

\section{Authors' affiliations}

S-Y Sheu, F Otterbach, K W Schmid, Institute of Pathology, University of Essen, 45122 Essen, Germany

R R Wenzel, Department of Internal Medicine, A. Ö. Krankenhaus Zell am See, 5700 Zell am See, Austria

C Kersting, Gerhard-Domagk-Institute of Pathology, University of Münster, 48149 Münster, Germany

R Merten, Department of Radiation Oncology, University Hospital Hamburg-Eppendorf, 20246 Hamburg, Germany

Correspondence to: Dr S-Y Sheu, Institut für Pathologie, Universitätsklinikum Essen, Hufelandstr. 55, 45122 Essen, Germany; sein-yi.sheu@medizin.uni-essen.de

Accepted for publication 10 May 2004 


\section{REFERENCES}

1 Chester W. Über Lipoidgranulomatose. Virchows Arch Pathol Anat 1930;279:561-602

2 Fink MG, Levinson DJ, Brown NL, et al. Erdheim-Chester disease. Case report with autopsy findings. Arch Pathol Lab Med 1991;115:619-23.

3 Bancroft LW, Berquist TH. Erdheim-Chester disease: radiographic findings in five patients. Skeletal Radiol 1998;27:127-32.

4 Reithmeier T, Trost HA, Wolf S, et al. Xanthogranuloma of the ErdheimChester type within the sellar region: case report. Clin Neuropathol 2002;21:24-8.

5 Schmidt HH, Gregg RE, Shamburek R, et al. Erdheim-Chester disease: low low-density lipoprotein levels due to rapid catabolism. Metabolism 1997;46:1215-19.

6 Resnick D, Greenway G, Genant H, et al. Erdheim-Chester disease. Radiology 1982; 142:289-95.

7 Atkins HL, Klopper JF, Ansari AN, et al. Lipid (cholesterol) granulomatosis (Chester-Erdheim disease) and congenital megacalices. Clin Nucl Med 1978;3:324-7.

8 Mahnel R, Tan KH, Fahlbusch R, et al. Problems in differential diagnosis of non Langerhans cell histiocytosis with pituitary involvement: case report and review of literature. Endocr Pathol 2002;13:361-8.
9 Bullmann C, Faust $M$, Hoffmann $A$, et al. Five cases with central diabetes insipidus and hypogonadism as first presentation of neurosarcoidosis. Eur J Endocrinol 2000;142:365-72.

10 Gachoud D, Blanc MH, Monnat A. [Infundibulitis, an unusual case of central diabetes insipidus.] Rev Med Suisse Romande 2002;122:549-51.

11 Sheen KC, Chang CC, Chang TC, et al. Thickened pituitary stalk with central diabetes insipidus: report of three cases. J Formos Med Assoc 2001;100:198-204.

12 Takao T, Asaba K, Tanaka H, et al. A case of lymphocytic infundibuloneurohypophysitis showing diabetes insipidus followed by anterior hypopituitarism associated with thrombasthenia. Endocr J 2000;47:285-91.

13 Tashiro T, Sano T, Xu B, et al. Spectrum of different types of hypophysitis: a clinicopathologic study of hypophysitis in 31 cases. Endocr Pathol 2002; 13:183-95.

14 Yap WM, Chuah KL, Tan PH. Langerhans cell histiocytosis involving the thyroid and parathyroid glands. Mod Pathol 2001;14:111-15.

15 Mohn A, Fahlbusch R, Dorr HG. Panhypopituitarism associated with diabetes insipidus in a girl with a suprasellar arachnoid cyst. Horm Res 1999;52:35-8.

16 Khamseh ME, Mollanai S, Hashemi F, et al. Erdheim-Chester syndrome, presenting as hypogonadotropic hypogonadism and diabetes insipidus. $J$ Endocrinol Invest 2002;25:727-9.

17 Folkerth RD, Price DL Jr, Schwartz M, et al. Xanthomatous hypophysitis. Am J Surg Pathol 1998;22:736-41. 